\title{
The Mechanism of Amphoteric Metals Cations Immobilization into Clay-Cement Mixtures
}

\author{
Agata STEMPKOWSKA ${ }^{1)}$
}

1) AGH University of Science and Technology, Faculty of Mining and Geoengineering, Cracow, Poland; email: stemp@agh.edu.pl

http://doi.org/10.29227/IM-2020-01-02

Submission date: $02-01-2020$ | Review date: 15-02-2020

\section{Abstract}

The article presents the possibilities of using special prepared binders to reduce the emission of ions from soil, and immobilize metals migration from waste deposits. Clay-cement slurries are mixtures containing in their compositions clinker binder and clay minerals, in this case they were Betchatów and Koniecpol clays. After hydratation process mixtures they create flexible and tight structures that are used, among others, as a barriers immobilizing the spread of pollution. The tests have shown that in the case of amphoteric metals, it is possible to accumulate almost $100 \%$ of the contamination using clay-cement suspensions. An attempt was also made to explain the mechanisms of ion retention in arised structures. The article presents three probable mechanism of amphoteric ions binding, the first is retention in the clay minerals interlayer spaces, the second is entrapment in CSH type phases formed during hydratation. Last possibility is formation of some new silicate structures.

Keywords: amphoteric ions, metals pollution, clay-cement mixtures, hydratation

\section{Introduction}

Many experimental works have shown the feasibility of waste materials in civil engineering and have been explored by several authors in many different fields such as for subbase course and road construction, (Spence et al. 2017) for manufacture of aggregates for concrete mixtures and also for cement, (Bogehtich et al. 2005, Collivignarelli et al. 2017, Dalton et al. 2004, Korotenko et al. 2018) for brick, (Andreola et al. 2001) and glass or glass-ceramic materials (Monterio et al. 2008), as a alternative fuel and hydroisolation barriers production (Wójcik et al. 2009).

The environmental compatibility is an important issue and the waste reuse can contribute to the pollutant release in the environment, especially when concrete is demolished or comes in contact with water (Chibuike et al. 2014, Kasmi et al. 2017, Malviya et al. 2006, Wang et al. 2010).

Some of the harmful elements have the amphoteric properties, which mean that they can behave as both the acid and base. Transition metals produce the inorganic compounds that show the strongest amphoteric properties. This property is very common for the hydroxides of the metals with a medium electronegativity. The amphoteric property of the compound is related to the ability of each element to create the anions and cations in the aqueous solution. As an example, the chromium ion, $\mathrm{Cr}^{3+}$ in the strong acidic solution forms the salt, $\mathrm{CrCl}_{3}$ (in the presence of abundance of chloride ions forms a complex ion). In the weak acidic and neutral solution, chromium ion precipitates as little soluble hydroxide $\mathrm{Cr}(\mathrm{OH})_{3}$. In that form chromium hydroxide in the alkalic solution dissolve to create chromium ions $\left[\mathrm{Cr}(\mathrm{OH})_{4}\right]-$ and has a tendency to migrate to the environment (Lafhaj et al. 2007, Stempkowska et al. 2017, Varchney et al. 2017, Zmijkowa et al. 2018).

The previous researches show that clay-cement mixtures have a very good immobilization properties for the metal cations (heavy metals, transition metals) (Wuana et al 2011, Andersen et al. 1994, Seip et al 1994, Wuana et al. 2011). Despite the successful inhibition there is the risk that amphoteric metals in the strong basic solution can form compounds easily dissolved in water. This article is a trial to explanation the relation between very strong basic clay-cement mixtures and possibility to release the harmful metal cations to the environment and also considers the possibility of the forming the silicate compounds in the reaction with sodium silicate (commonly known as a waterglass), that is addend to the clay-cement hydrobariers to control the hydratation process (Zhang et al 2008, Wang et al 2017, Bashir et al. 2011).

\section{Materials and Methods}

The various samples of clay-cement binders were prepared using as a base two different types of the mineral compounds, the first one was Koniecpol clay and the second one was Bełchatów clay, and the third type of samples the waste ashes were used. In this preparation as a filler the medium mesh size sand was imputed. Samples contain also 1\% wt of sodium silicate (waterglass) type R145 (izak et al 2015, Stempkowska et al. 2018) Bełachtów clay is monomineral material containing almost exclusively beidellite, that is calcium and sodium aluminosilicate, with a general chemical formula $\mathrm{Na}_{0.5} \mathrm{Al}_{2}\left(\mathrm{Si}_{3.5} \mathrm{Al}_{0.5}\right) \mathrm{O}_{10}(\mathrm{OH})_{2} \cdot \mathrm{n}\left(\mathrm{H}_{2} \mathrm{O}\right)$. Koniecpol clay is a loose multimineral rock, containing in its composition about $50 \%$ wt. of vermiculite, that is aluminium, iron nad magnesium aluminosilicate, with approximate chemical formula $(\mathrm{Mg}, \mathrm{Fe}, \mathrm{Al})_{3}(\mathrm{Al}, \mathrm{Si})_{4} \mathrm{O}_{10}(\mathrm{OH})_{2} \cdot 4 \mathrm{H}_{2} \mathrm{O}$, the rest of the material is quartz and a small amount of carbonates.

The standards for hydroisolation slurry preparation indicate the quantity of sodium silicate should not exceed $1 \%$ of composition because the higher values of that has a negative impact on the rheological properties (Wójcik et al. 2015, Stempkowska et al 2011). However for academic purposes 
and comparison study, the samples with high concentration of sodium silicate and the samples without it were tested.

Amount and type of the compounds in the samples are presented in the Table 1, as well as the $\mathrm{pH}$ values for that type of mixtures. The $\mathrm{pH}$ index of the samples is stable and characteristic for clay-cement mixtures. The acronyms of the samples indicate respectively, the type of additive used (P25 - ash, $\mathrm{K}$ - Koniecpol clay, B - Bełchatów clay) and then content of cement and water glass.

The slurry mixes were spiker with various amphoteric hydroxides of metals that are considered as a harmful after Minister of Environment act „Standards for soil and earth quality" publicized in 2001. For the purposes of this research, there elements were chosen: Lead II Zinc (II) and Chromium (III). The standards for the those elements contents are show in Table 2.

The hydroxides of those elements were added to the slurry mixtures in the quantity exceed twice the standards for its concentration in the soil, with the parameters as follows:

- $\quad$ Lead $-2000 \mathrm{mg} / \mathrm{kg}$

- $\quad$ Zinc $-40 \mathrm{mg} / \mathrm{kg}$

- Chromium - $1600 \mathrm{mg} / \mathrm{kg}$
On account of slurry high $\mathrm{pH}$ factor, the hydroxides started dissolve and created aqua soluble complex ions such as: $\left[\mathrm{Cr}(\mathrm{OH})_{4}\right]^{-},\left[\mathrm{Zn}(\mathrm{OH})_{4}\right]^{2-},\left[\mathrm{Pb}(\mathrm{OH})_{4}\right]^{2-}$. In this state investigated compouds should be sucesfully inhibited in clay-cement slurry.

The samples were saturated with distilled water and extraction was allowed to occur for $48 \mathrm{~h}$. The samples were placed in special cylinders and forced to flow by them distilled water, under constant pressure. The hydraulic gradient was generated by compressed air at stabilized pressure. Compressed air displaced distilled water from the tank which through a sample in the measuring chamber water flowed into the filtrate container. The samples were filtered under the pressure of $1 \mathrm{~atm}$ to obtain $100 \mathrm{ml}$ of extract. The filtrate was subjected to analytical test. The filtration system has been shown on figure 1 .

\section{Results and Discussion}

The physical and chemical characteristics of effluents are presented in Table 3 and 4 and concentration of metals cations are show the Figure 2. The trace amounts of the metal ions were observed in the samples. The percentage of the

Tab. 1. Composition of clay-cement mixtures

Tab. 1. Składy mieszanin iłowo cementowych

\begin{tabular}{|c|c|c|c|c|c|}
\hline Sample & $\begin{array}{c}\text { Sample } \\
\text { mass } \\
\text { [g] }\end{array}$ & $\begin{array}{c}\text { Sodium } \\
\text { silicate } \\
\text { [g] }\end{array}$ & $\begin{array}{c}\text { cement } \\
{[\mathrm{g}]}\end{array}$ & $\begin{array}{c}\text { soil } \\
{[\mathrm{g}]}\end{array}$ & pH \\
\hline P25.50.0 & 106,3 & 0 & 53,2 & 53,2 & 13,03 \\
\hline P25.50.1 & 109,2 & 1,09 & 54,6 & 54,6 & 13,29 \\
\hline P25.50.2 & 105,6 & 2,11 & 52,8 & 52,8 & 13,44 \\
\hline P25.60.0 & 106,5 & 0 & 63,9 & 42,6 & 13,27 \\
\hline P25.60.1 & 102,8 & 1,03 & 61,7 & 41,1 & 13,48 \\
\hline $\mathbf{P} 25.60 .2$ & 108,1 & 2,16 & 64,9 & 43,2 & 13,48 \\
\hline P25.70.0 & 105,6 & 0 & 73,9 & 31,7 & 13,37 \\
\hline P25.70.1 & 100,3 & 2,01 & 70,2 & 30,1 & 13,54 \\
\hline P25.70.2 & 109,2 & 2,18 & 76,4 & 32,8 & 13,25 \\
\hline K.50.0 & 107,0 & 0 & 53,5 & 53,5 & 13,25 \\
\hline K.50.1 & 103,1 & 1,03 & 51,5 & 51,5 & 13,34 \\
\hline K.50.2 & 105,4 & 2,11 & 52,7 & 52,7 & 13,34 \\
\hline K.60.0 & 108,5 & 0 & 65,1 & 43,4 & 13,15 \\
\hline K.60.1 & 109,2 & 1,09 & 65,5 & 43,7 & 13,58 \\
\hline K.60.2 & 106,7 & 2,13 & 64,0 & 42,7 & 13,43 \\
\hline K.70.0 & 108.0 & 0 & 75,6 & 32,4 & 13,48 \\
\hline K.70.1 & 106,1 & 1,06 & 74,3 & 31,8 & 13,37 \\
\hline K.70.2 & 101,8 & 2,04 & 71,3 & 30,5 & 13,54 \\
\hline B.50.0 & 107,6 & 0 & 53,8 & 53,8 & 13,43 \\
\hline B.50.1 & 102,3 & 1,02 & 51,2 & 51,2 & 13,25 \\
\hline B.50.2 & 105,1 & 2,10 & 52,6 & 52,5 & 13,34 \\
\hline B.60.0 & 104,3 & 0 & 62,6 & 41,7 & 13,15 \\
\hline B.60.1 & 108,2 & 1,08 & 64,9 & 43,3 & 13,23 \\
\hline B.60.2 & 105,6 & 2,11 & 63,4 & 42,2 & 13,58 \\
\hline B.70.0 & 107,5 & 0 & 75,3 & 32,2 & 13,25 \\
\hline B.70.1 & 106,3 & 1,06 & 74,4 & 31,9 & 13,15 \\
\hline B.70.2 & 102,8 & 2,06 & 71,9 & 30,8 & 13,23 \\
\hline
\end{tabular}


leaching of this ions to the soil is very low, therefore it is not significant for the study of cement-clay slurry as the hydroisolation barriers.

Figure 2. below, show the relationship between cation charge and concentrations of elements in effluent after washing. The higher concentration value of chromium ions can be caused by different ions migration mechanism. The maximum concentration is $0,45 \mathrm{mg} / \mathrm{L}$ which is considered as trace quality.

The results show negative dependence between cations leaching and the compositions of slurry mixtures samples. The data show no relation between ions migrations and the percentage of sodium silicate in the composition of binder. The observation was made that the type of materials (like clays or ashes) used in binder's composition should not affect the accumulation of harmful elements.

\subsection{The mechanizm of ion immobilisation}

A characteristic feature of clay-cement binders is that throughout the en tire bonding area they behave like viscoplastic fluids and there is no rigid crystal structure created e.g. characteristic for concrete. Thanks to this, the connection of the linker phases contained in the material and fine disper- sion Clay fractions ensure high tightness and harmful substances retention capacity.

The impact of foreign ions $\mathrm{Pb}^{2+}, \mathrm{Zn}^{2+}, \mathrm{Cr}^{3+}$ within the structure of clay cement mixtures was investigated, and there is most likely three possibilities, of ion immobilization:

- interlayer position in clays,

- intermolecular bonds in cement

- $\quad$ or ash or arising different structure.

In the light of these facts, the fundamental understanding of clay-cement mixtures chemistry remains as an important issue.

Ion exchange in clays is dependent on the crystalline structure of the mineral and on the chemical composition of any solution in contact with the mineral. The structures of clay minerals are briefly described to provide a background for the discussion of their ion-exchange reactions. Ion exchange in these minerals is a reversible chemical reaction that takes place between ions held near a mineral surface by unbalanced electrical charges within the mineral framework and ions in a solution in contact with the mineral. Generally the excess charge on the mineral is negative, and it attracts cations

Tab. 2. The standards for the contents of metals in the different type of soils

Tab. 2. Zawartości normowe metali w różnych typach gruntów

\begin{tabular}{|c|c|c|c|c|c|c|c|c|c|c|}
\hline \multirow{6}{*}{ Lp } & \multirow{6}{*}{ pollution } & \multirow{6}{*}{ type A } & \multicolumn{4}{|c|}{ type B } & \multicolumn{4}{|c|}{ type $C$} \\
\hline & & & \multicolumn{8}{|c|}{ Depth [m] } \\
\hline & & & $0-0,03$ & \multicolumn{2}{|c|}{$0,3-15,0$} & \multicolumn{2}{|c|}{$>15$} & $0-2$ & \multicolumn{2}{|c|}{$2-15$} \\
\hline & & & & \multicolumn{7}{|c|}{ Water infiltration $[\mathrm{m} / \mathrm{s}]$} \\
\hline & & & & up to & below & up to & below & & up to & below \\
\hline & & & & \multicolumn{2}{|c|}{$1 \times 10^{-7}$} & \multicolumn{2}{|c|}{$1 \times 10^{-7}$} & & \multicolumn{2}{|c|}{$1 \times 10^{-7}$} \\
\hline 1 & 2 & 3 & 4 & 5 & 6 & 7 & 8 & 9 & 10 & 11 \\
\hline \multicolumn{11}{|c|}{ METALS [mg/kg] } \\
\hline 1 & Chromium & 50 & 150 & 150 & 190 & 150 & 380 & 500 & 150 & 800 \\
\hline 2 & Zinc & 1 & 4 & 5 & 6 & 4 & 10 & 15 & 6 & 20 \\
\hline 3 & Lead & 50 & 100 & 100 & 200 & 100 & 200 & 600 & 200 & 1000 \\
\hline
\end{tabular}

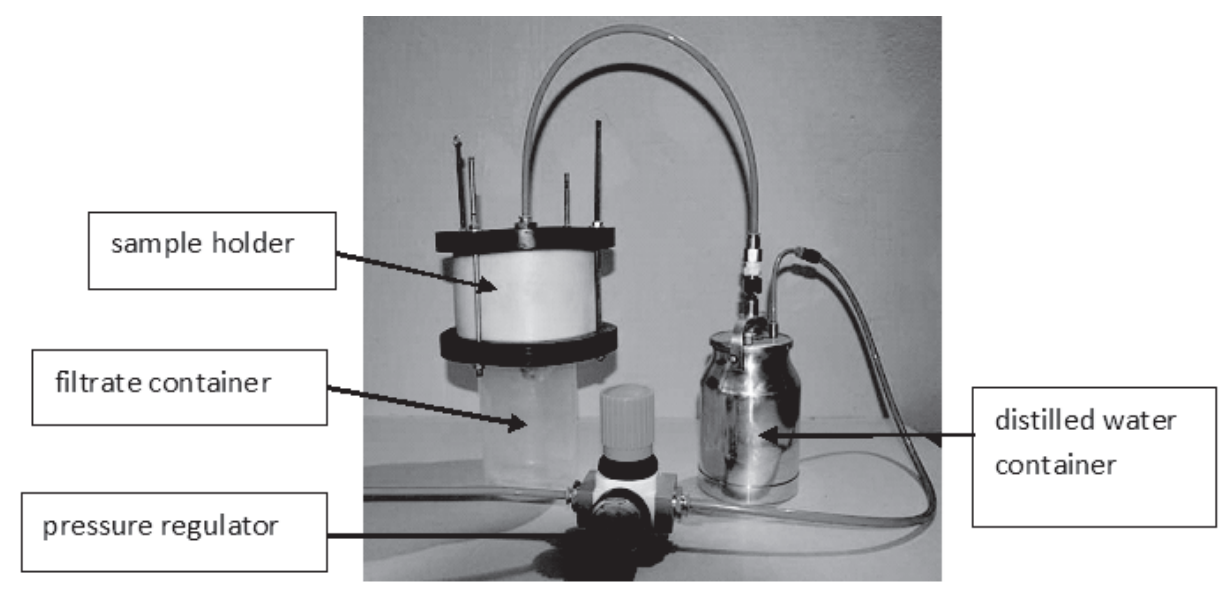

Fig. 1. Filtration set

Rys. 1. Zestaw filtracyjny 
from the solution to neutralize this charge. The chemical reactions in ion exchange follow the law of mass action, but the reactions are restricted by the number of exchange sites on the mineral and by the strength of the bonding of the exchangeable cations to the mineral surface.

In this experiment two samples were added clay agent, the first one Koniecpol clay, which is multimineral (contains also sand, and anthem types of clays) , but more than $50 \%$ is vermicullite - smektyte type. Second was Bełchatów Clay, monomineral montmoryllonite - beidellite type. Each clay mineral has a range of exchange capacities because of differences in structure and in chemical composition, but in this case both of them are 2:1 and expanding structure which means that they can exchange cations. The ranges (in milliequivalents per 100 grams) are; montmorillonite, 70-100; illite, 10-40; vermiculite, 100-150 (Pardo et al. 2018, Esaifan et al. 2019). In the available space between individual interlayer there are exchangeable cations and water molecules. When introducing different types of cations, it becomes possible that this space is naturally inaccessible, and interchangeable cations are not replaceable. Model of structure is shown on figure 3. In interchangeable cation position may substitute zinc, lead or chromium, and because of charge and ionic radius chromium will be privileged.

The samples were filtered under the same pressure, but eluent was nitrogen $\mathrm{V}$ acid because solubility of arising salts, for example zinc, or lead chlorides are unsoluble, The concentration was $10 \%$ wt quite low, because of undesiderable corrosion. As you may notice, again have higher concentration value of chromium ions be caused by different ions migration mechanizm, and cation charge. Lead and zinc still very low. And finally we can observe, samples with water glass addition, inhibits more elements than samples without it. Results are included in table 4 and on figure 4 , and demonstrate the effective immobilization of amphoteric ions.

Second possibility by immobilizing ions are intermolecular bonds in cement and ash. In the assumption cement and ash have similar hydratation possibilities. The samples were mixed before the hydratation process, so the phenomenon of ion retention was considered taking into account the non-hydrated phases. Of course, after mixing with water and solidifying the samples, the clinker phases go into CSH gels, and proper immobilization already occurs in hydrated minerals. There are a few clinker phases such as follows: alite $\mathrm{C}_{3} \mathrm{~S}$, be-

Tab. 3. The concentration of the selected metal cations in the effluents, determined by ASA method Tab. 3. Stężenie wybranych metali w przesączach wodnych

\begin{tabular}{|c|c|c|c|}
\hline Sample & $\begin{array}{c}\mathrm{Pb}^{2+} \\
{[\mathrm{mg} / \mathrm{l}]}\end{array}$ & $\begin{array}{c}\mathrm{Zn}^{2+} \\
{[\mathrm{mg} / \mathrm{l}]}\end{array}$ & $\begin{array}{c}\mathrm{Cr}^{3+} \\
{[\mathrm{mg} / \mathrm{l}]}\end{array}$ \\
\hline P25.50.0 & 0,083 & 0,0033 & 0,433 \\
\hline P25.50.1 & 0,071 & 0,0027 & 0,333 \\
\hline P25.50.2 & 0,071 & 0,0076 & 0,322 \\
\hline P25.60.0 & 0,073 & 0,0029 & 0,286 \\
\hline P25.60.1 & 0,068 & 0,0012 & 0,296 \\
\hline P25.60.2 & 0,067 & 0,0087 & 0,222 \\
\hline P25.70.0 & 0,047 & 0,0031 & 0,271 \\
\hline P25.70.1 & 0,038 & 0,0045 & 0,231 \\
\hline P25.70.2 & 0,053 & 0,0012 & 0,246 \\
\hline K.50.0 & 0,135 & 0,0045 & 0,377 \\
\hline K.50.1 & 0,081 & 0,0023 & 0,361 \\
\hline K.50.2 & 0,083 & 0,0031 & 0,343 \\
\hline K.60.0 & 0,085 & 0,0022 & 0,327 \\
\hline K.60.1 & 0,056 & 0,0056 & 0,276 \\
\hline K.60.2 & 0,066 & 0,0037 & 0,273 \\
\hline K.70.0 & 0,082 & 0,0045 & 0,254 \\
\hline K.70.1 & 0,077 & 0,0023 & 0,241 \\
\hline K.70.2 & 0,079 & 0,0029 & 0,268 \\
\hline B.50.0 & 0,048 & 0,0031 & 0,453 \\
\hline B.50.1 & 0,045 & 0,0045 & 0,439 \\
\hline B.50.2 & 0,068 & 0,0012 & 0,376 \\
\hline B.60.0 & 0,057 & 0,0026 & 0,365 \\
\hline B.60.1 & 0,051 & 0,0045 & 0,329 \\
\hline B.60.2 & 0,031 & 0,0070 & 0,366 \\
\hline B.70.0 & 0,042 & 0,0045 & 0,361 \\
\hline B.70.1 & 0,015 & 0,0023 & 0,275 \\
\hline B.70.2 & 0,063 & 0,0026 & 0,243 \\
\hline
\end{tabular}


lite $\mathrm{C}_{2} \mathrm{~S}, \mathrm{C}_{4} \mathrm{AF}$ and $\mathrm{C}_{3} \mathrm{~A}$. There is about $65 \%$ alite in clinker, so other phases were skipped. Structure of alite is very interesting, tricalcium silicate $\mathrm{C}_{3} \mathrm{~S}$ has structure with isolated $\left[\mathrm{SiO}_{4}\right]$ which are connected by $\mathrm{Ca}-\mathrm{O}$ polyhedra. The aproximate chemical formula is $3 \mathrm{CaO} \cdot \mathrm{SiO}_{2}\left(\mathrm{C}_{3} \mathrm{~S}\right.$ in cement chemist notation), but in fact the structure is different, alite exhibits a complex polymorphism depending on impurities. Picture shows pure alite monoclinic mineral structure but alite found in clinker is a solid solution with a highly defective structure. Oxygen atoms are present in two different coordinations - in $\mathrm{Si}$ thetraedres, and in $\mathrm{Ca}$ - octaedres coordinated by 6 calcium ions. And for that reason, cations can be bulit-in the structure during hydratation process (Horst et al 2015). The influence of individual ions on the structure of $\mathrm{C}_{3} \mathrm{~S}$ has been extensively studied in past decades (Zhang et al. 2011). The higher crystal symmetry is achived without substituted ions. By defining a quantity called structure different factor D, in which the structural parameters such as radius, electronegativity, coordination numer of the substituent ion were taken into account with relation to $\mathrm{Ca}^{2+}$. Table 5 shown the relation between chemical structure parameters of investigated ions $\mathrm{Pb}^{2+}, \mathrm{Zn}^{2+}, \mathrm{Cr}^{3+}$, and their substitution patterns and abbilities to unstabilize alite crystals. Absolute value of D factor greater than or equal 0,2 destabilized structure. Conclusion is that alite structure immobilize amphoteric metals but lead could be dangerous for stable structure.

$D=\frac{\mathrm{Z} \cdot \Delta \mathrm{x} \cdot\left(\mathrm{R}_{\mathrm{Ca} 2^{*}}-\mathrm{R}\right)}{\mathrm{R}_{\mathrm{Ca} 2^{*}}}$

D - structure different factor - related to calcium.

And in following formula:

$\mathrm{Z}$ - ion charge,

$\Delta \mathrm{x}$ - elektronegativity difference between ion and calcium, $\mathrm{R}$ - ion radius,

$\mathrm{R}_{\mathrm{Ca} 2+}-$ calcium cation radius.

Absolute value of $\mathrm{D}$ factor greater than or equal $0,2 \mathrm{de}-$ stabilized structure. These results indicate that alite structure immobilize amphoteric metals but lead could be dangerous for stable.

\subsection{Quality precipitation of silicates of the selected ampho- teric metal cations.}

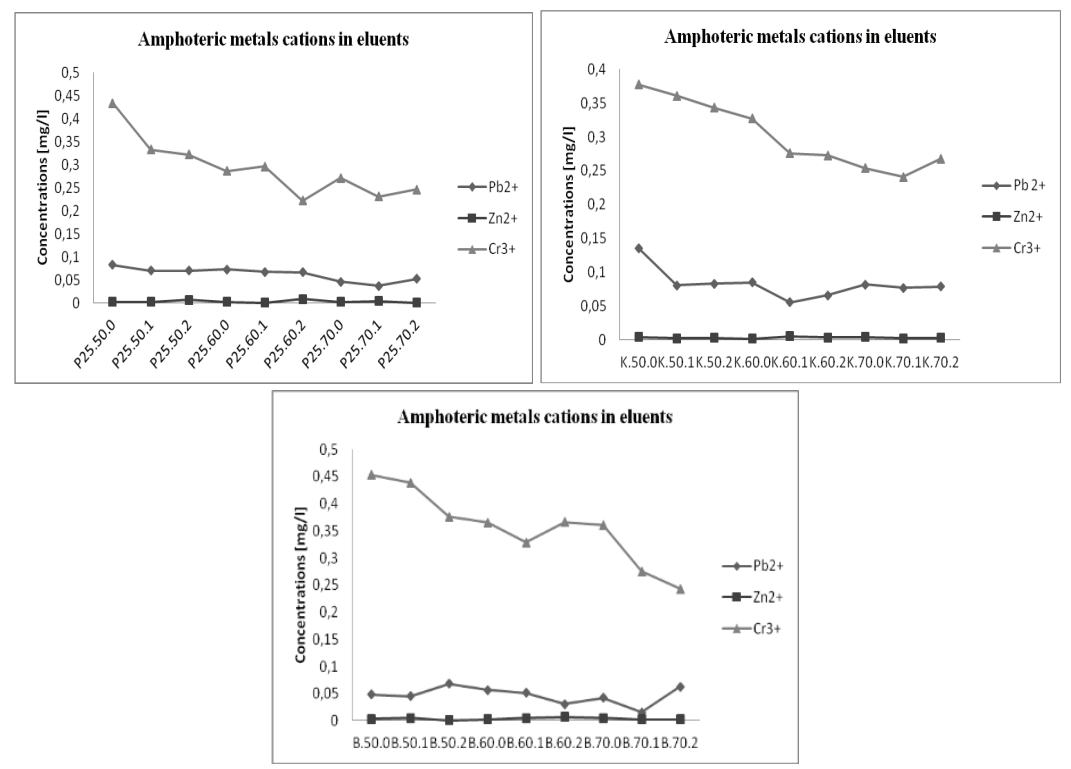

Fig. 2. Amfoteric metals water condition leaching test

Rys. 2. Wymywalność metali amfoterczynch w warunkach wodnych

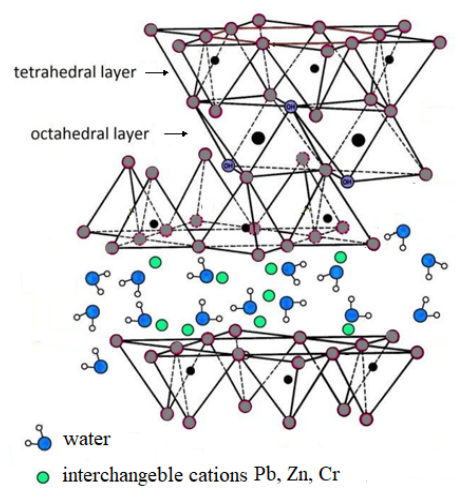

Fig. 3. Clay mineral 2:1 type structure

Rys. 3. Struktura minerału ilastego typu 2:1 


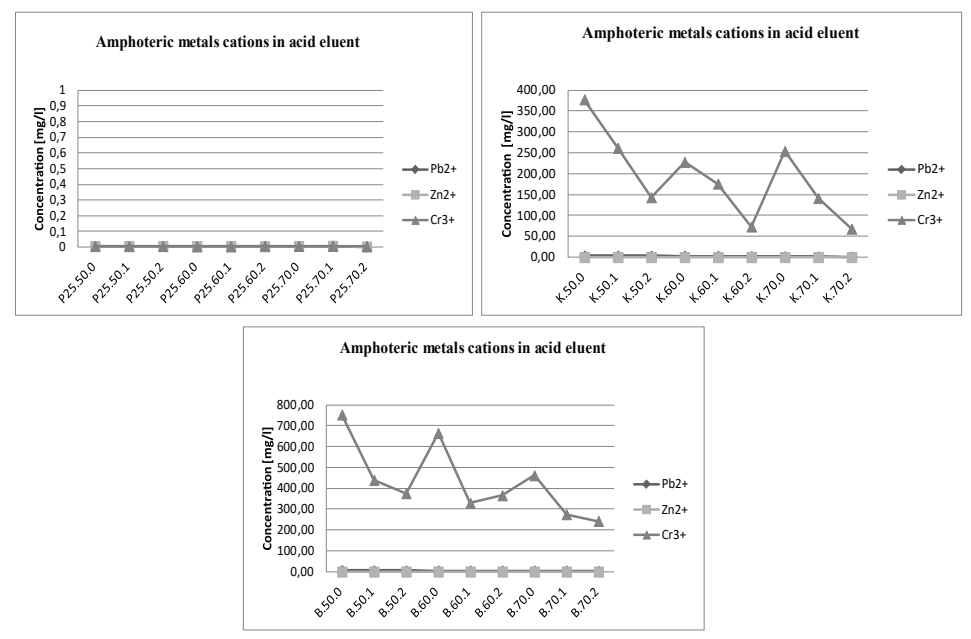

Fig. 4. Amfoteric metals low $\mathrm{pH}$ condition leaching test Rys. 4. Wymywalność metali amfoterycznych w warunkach niskiego pH

Tab. 5. Parameters of ions with substitution pattern Tab. 5. Parametry jonów ze wzorem podstawienia

\begin{tabular}{|l|c|c|c|}
\hline & $\mathbf{P b}^{2+}$ & $\mathbf{Z n}^{2+}$ & $\mathbf{C r}^{\mathbf{2}^{+}}$ \\
\hline Ionic radius [pm] & 132 & 74 & 64 \\
\hline Coordination number & 4 & 4 & 6 \\
\hline Electronegativity & 1,87 & 1,65 & 1,66 \\
\hline Substitution pattern & $\mathrm{Pb} \rightarrow \mathrm{Ca}$ & $\mathrm{Zn} \rightarrow \mathrm{Ca}$ & $\mathrm{Cr} \rightarrow \mathrm{Ca} / \mathrm{Al}$ \\
\hline D factor & $-1,32$ & 0,328 & 0,7 \\
\hline
\end{tabular}

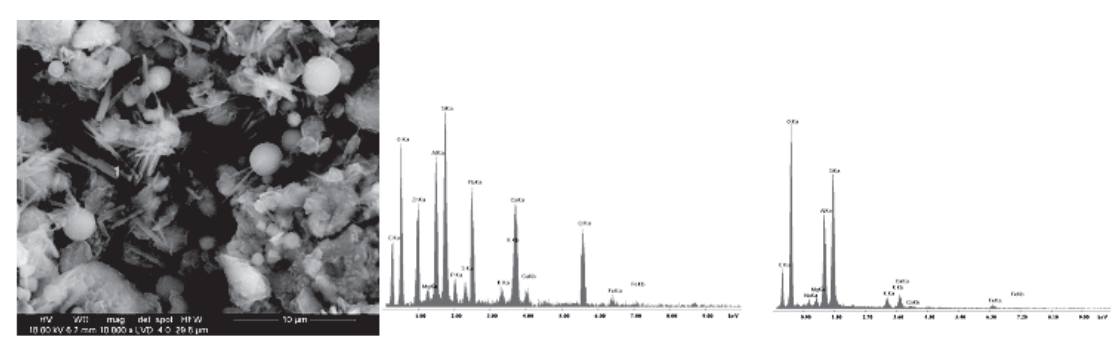

Fig. 5. SEM and EDS analysis of sample with $25 \%$ ash content Rys. 5. SEM i EDS próbki zawierającej $25 \%$ popiołu
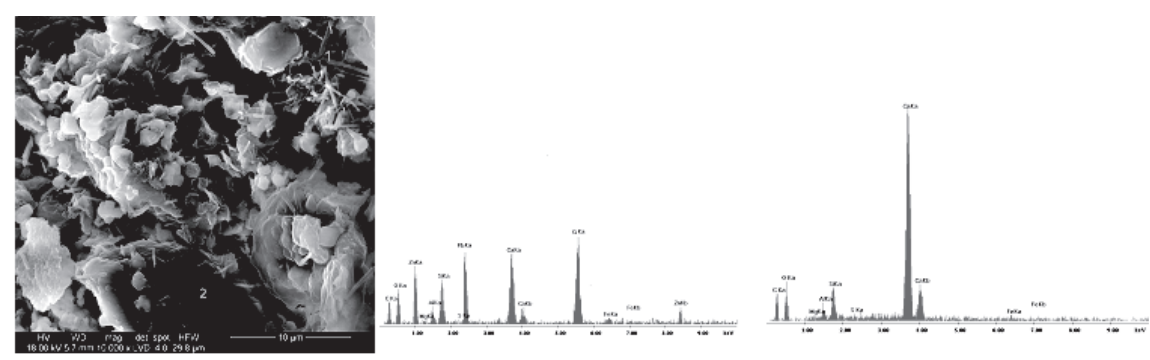

Fig. 6. SEM and EDS analysis of sample based on Koniecpol clay Rys. 6. SEM i EDS próbki zawierającej ił Koniecpol
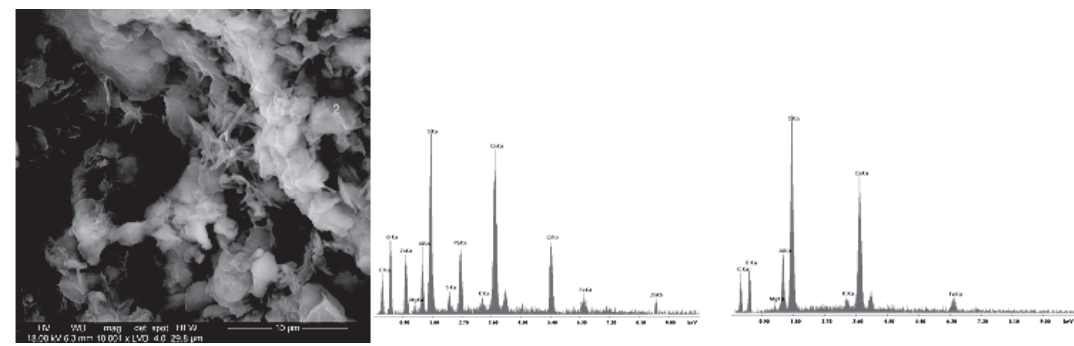

Fig. 7. SEM and EDS analysis of sample based on Bełchatów clay Rys. 8. SEM i EDS próbki zawierającej ił Bełchatów 
Tab. 4. The concentration of the selected metal cations in the acid effluents, determined by ASA metod

Tab. 4. Stężenie kationów metali w przesączach kwasowych

\begin{tabular}{|c|c|c|c|}
\hline Sample $\mathrm{HNO}_{3}$ & $\begin{array}{c}\mathrm{Pb}^{2+} \\
{[\mathrm{mg} / \mathrm{l}]}\end{array}$ & $\begin{array}{c}\mathrm{Zn}^{2+} \\
{[\mathrm{mg} / \mathrm{l}]}\end{array}$ & $\begin{array}{c}\mathrm{Cr}^{3+} \\
{[\mathrm{mg} / \mathrm{l}]}\end{array}$ \\
\hline P25.50.0 & 0,007 & 0,006 & 0,0076 \\
\hline P25.50.1 & 0,007 & 0,007 & 0,0063 \\
\hline P25.50.2 & 0,007 & 0,007 & 0,0067 \\
\hline P25.60.0 & 0,006 & 0,006 & 0,0049 \\
\hline P25.60.1 & 0,007 & 0,007 & 0,0042 \\
\hline P25.60.2 & 0,007 & 0,005 & 0,0087 \\
\hline P25.70.0 & 0,007 & 0,007 & 0,0071 \\
\hline P25.70.1 & 0,008 & 0,008 & 0,0085 \\
\hline P25.70.2 & 0,003 & 0,003 & 0,0072 \\
\hline K.50.0 & 3,54 & 0,005 & 377,8 \\
\hline K.50.1 & 3,38 & 0,003 & 261,4 \\
\hline K.50.2 & 3,28 & 0,001 & 143,4 \\
\hline K.60.0 & 3,09 & 0,002 & 227,8 \\
\hline K.60.1 & 2,96 & 0,006 & 176,1 \\
\hline K.60.2 & 2,27 & 0,007 & 73,3 \\
\hline K.70.0 & 2,08 & 0,005 & 254,0 \\
\hline K.70.1 & 1,78 & 0,003 & 141,4 \\
\hline K.70.2 & 1,08 & 0,009 & 68,1 \\
\hline B.50.0 & 6,05 & 0,001 & 753,5 \\
\hline B.50.1 & 5,45 & 0,005 & 439,4 \\
\hline B.50.2 & 5,07 & 0,002 & 376,0 \\
\hline B.60.0 & 5,06 & 0,006 & 665,1 \\
\hline B.60.1 & 4,75 & 0,005 & 329,3 \\
\hline B.60.2 & 4,03 & 0,007 & 366,0 \\
\hline B.70.0 & 4,04 & 0,005 & 471,8 \\
\hline B.70.1 & 4,02 & 0,003 & 275,3 \\
\hline B.70.2 & 3,06 & 0,006 & 243,1 \\
\hline
\end{tabular}

The experiment was carried to confirm the redirection about the possibility that certain amphoteric metal cations may precipitate as insoluble and stable salts in strong alkaline solution. To each solution of soluble salts of the selected metal cations, the sodium silicate was added, to observe if the precipitate will form. The experiment was conducted in the following conditions.

- the concentration of $20 \%$ of the following salts $\mathrm{PbNO}_{3}, \mathrm{ZnCl}_{2}$ and $\mathrm{CrCl}_{3}$

- $\quad$ the sodium silicate $\mathrm{Mk}=2,5$

- $\quad$ reagents in the proportion $1: 1$

To accelerate the rate of re action the samples were put in the laboratory drier at 80 degree Celsius. All samples formed the insoluble precipitant as follows:

- monohydrate lead II silicate $\mathrm{PbO} \cdot \mathrm{SiO}_{2} \cdot \mathrm{H}_{2} \mathrm{O}$ (white crystals)

- monohydrate zinc II silicate $\mathrm{ZnO} \cdot \mathrm{SiO}_{2} \cdot \mathrm{H}_{2} \mathrm{O}$ (blue opalescent gelatinous precipitate)

- monohydrate chromium III silicate $\mathrm{Cr}_{2} \mathrm{O}_{3} \cdot \mathrm{SiO}_{2} \cdot \mathrm{H}_{2} \mathrm{O}$ (pale green crystals)
Additional validation of creating unsoluble chemical bounds were obtained by SEM images with EDS analysis (figure 5-7). The EDS analysis shows that transition metals content is significantly increased, while the contents of impurity elements $(\mathrm{Zn}, \mathrm{Cr}, \mathrm{Pb})$. These metals are immobilized in cement phases (long tiny crystals).

\section{Conclusions}

1. Clay cement mixtures retain amphoteric metals

- part as interchangable cations in clay minerals structures

- part as cations substitute during the formation of the alite phase

- and some form new structures by reaction with waterglass

2. The mechanism of cation retention depends on the quantitative composition of the mixture, but inhibition in the structure of the alite is the strongest

3. Chromium has an affinity for clay minerals, in case of ion radius, charge and negative $\mathrm{D}$ factor value - confirmation by acid leaching

4. Indirect conclusion - complexes ion have weaker bonds than the hydration reaction 


\section{Literatura - References}

1. Andersen S. Ødegård S. Hans M.Seip 1994 Background levels of heavy metals in Polish forest soils Ecological Engineering, Volume 3, Issue 3, pp 245-253

2. Andreola F, Barbieri L, Corradi A, Lancellotti I, Manfredini T., 2001 The possibility to recycle solid residues of the municipal waste incineration into a ceramic tile body. J Mater Sci 36:4869-4873. doi: 10.1023/A:1011823901409

3. Bashir MJK, Aziz HA, Yusoff MS 2011 New sequential treatment for mature landfill leachate by cationic/anionic and anionic/cationic processes: optimization and comparative study. J Hazard Mater vol 186 pp 92-102

4. Boghetich G, Liberti L, Notarnicola M, Palma M, Petruzzelli D 2005 Chloride extraction for quality improvement of municipal solid waste incinerator ash for the concrete industry. Waste Manag Res 23:57-61. doi: 10.1177/0734242X05051017

5. Chibuike G. U., Obiora S. C. 2014 Heavy Metal Polluted Soils: Effect on Plants and Bioremediation Methods Applied and Environmental Soil Science Article ID 752708, http://dx.doi.org/10.1155/2014/752708

6. Collivignarelli, M.C., Abbà, A., Sorlini, S. et al. 2017 Evaluation of concrete production with solid residues obtained from fluidized-bed incineration of MSW-derived solid recovered fuel (SRF) J Mater Cycles Waste Manag) 19: 1374. https://doi.org/10.1007/s10163-016-0523-y

7. Dalton J.L, Gardner K.H, Seager T.P, Weimer M.I, Spear J.C.M, Magee B.J 2004 Properties of Portland cement made from contaminated sediments. Resour Conserv Recycl vol 41pp 227-241

8. Esaifan M., LN. Warr, G. Grathoff, T. Meyer, MT Schafmeister, A. Kurt, H 2019. Testrich Synthesis of Hydroxy-Sodalite/Cancrinite Zeolites from Calcite-Bearing Kaolin for the Removal of Heavy Metal Ions in Aqueous Media, Minerals, vol 9(8), pp 484;

9. Horst ML, Wensheng Z, 2015 Research review of cement clinker chemistry, Cement and Concrete Research vol 78 pp 24-37

10. Izak P., Wójcik Ł., Słowikowski D., 2015 Rheology of soil binder dispersions Materiały Ceramiczne = Ceramic Materials / Polskie Towarzystwo Ceramiczne, Kraków ; vol 67 pp 158-163

11. Kasmi, A., Abriak, NE., Benzerzour, M. et al. 2017. Environmental impact and mechanical behavior study of experimental road made with river sediments: recycling of river sediments in road construction J Mater Cycles Waste Manag 19: 1405. https://doi.org/10.1007/s10163-016-0529-5

12. Korotenko E., Hendrych J., Mašin P., Solidification of Sludge from Waste Water Treatment, Inżynieria Mineralna Journal of the Polish Mineral Engineering Society, No 1(41), p. 103-110, DOI: 10.29227/IM-2018-01-17

13. Lafhaj Z, Samara M, Agostini F, Boucard L, Skoczylas F, Depelsenaire G 2007 Polluted river sediments from the North region of France: treatment with Novosol process and valorization in clay bricks. Constr Build Mater vol 148 pp 606-612

14. Malviya, R. Chaudhary, R. J 2006 8: 78. https://doi.org/10.1007/s10163-005-0139-0 Evaluation of leaching characteristics and environmental compatibility of solidified/stabilized industrial waste Mater Cycles Waste Manag

15. Monteiro RCC, Figueiredo CF, Alendouro MS, Ferro MC, Davim EJR, Fernandes MHV 2008 Characterization of MSWI bottom ashes towards utilization as glass raw material. Waste Manag 28(7):1119-1125. doi: 10.1016/j. wasman.2007.05.004

16. Pardo L, Cecilia JA, Lopez-Moreno C, Hernandez V, Pozo M, Bentabol JM, Franco F, 2018 Influence of the Structure and Experimental Surfaces Modifications of 2:1 Clay Minerals on the Adsorption Properties of Methylene Blue Minerals, vol 8(8), pp 359; https://doi.org/10.3390/min8080359

17. Prawo ochrony środowiska (Dz.U. Nr 62, poz. 627) http://prawo.sejm.gov.pl/isap.nsf/DocDetails.xsp?id=WDU20010620627

18. Seip H. M., Pawałowski L. Sulliven T., 1994 Environmental degradation dur to heavy metals and acidifying deposition - A Polish-Scandinavian workshop Ecological Engineering Volume 3, Issue 3, pp 205-206

19. Spence W. P., Kultermann E. 2017 Construction Materials, Methods and Techniques CENGAGE Learning

20. Stempkowska A., Wójcik Ł., Izak P., Staszewska M., Mastalska-Popławska J., 2018 Investigation of post-industrial pollutions' immobilization in a hydraulic self-solidifying clay-cement binder IOP Conference Series: Materials Science and Engineering vol. 427 pp 1-10

21. Stempkowska A., Izak P., Mastalska-Popławska J., 2017 Selected elements cations exchange in acidic medium on sorbents surface based on modified brown coal Gospodarka Surowcami Mineralnymi = Mineral Resources Management ; vol. 33 iss. 1, pp. 139-149. 
22. Stempkowska A., Wójcik Ł., Izak P., . 2011 Pseudothixotropic properties of clay-cement sluries Materiały Ceramiczne $=$ Ceramic Materials / Polskie Towarzystwo Ceramiczne, Kraków ;. vol 6, pp. 278-282

23. Varshney, S., Jain, P., Srivastava, S. J 2017 Application of ameliorated wood pulp to recover Cd(II), $\mathrm{Pb}$ (II), and $\mathrm{Ni}(\mathrm{II})$ from e-waste, Mater Cycles Waste Managment https://doi.org/10.1007/s10163-016-0539-3

24. Wang L. K., Yung-Tse Hung, Shammas N. K. 2010 Handbook of Advanced Industrial and Hazardous Wastes Treatment, CRC Press

25. Wang, D., Liu, D., Tao, L. et al. 2017 The impact on the effects of leachate concentrates recirculation for different fill age waste, J Mater Cycles Waste Manag https://doi.org/10.1007/s10163-016-0508-X

26. Wójcik Ł., Izak P., Kuś R., 2009 The influence of composition changes on properties of clay-cement binders Materiały Ceramiczne $=$ Ceramic Materials $/$ Polskie Towarzystwo Ceramiczne, Kraków, Vol 61, pp 27-30

27. Wójcik Ł., Izak P., Mastalska-Popławska J., Gajek M., 2015 Clay-cement suspensions - rheological and functional properties Journal of Physics. Conference Series, vol. 790, pp 1-7.

28. Wuana R. A., Okieimen F. E. 2011, Heavy Metals in Contaminated Soils: A Review of Sources, Chemistry, Risks and Best Available Strategies for RemediationI SRN Ecology Article ID 402647, http://dx.doi.org/10.5402/2011/402647

29. Wuana R. A., Okieimen F. E. 2011, Heavy Metals in Contaminated Soils: A Review of Sources, Chemistry, Risks and Best Available Strategies for RemediationI SRN Ecology Article ID 402647, http://dx.doi.org/10.5402/2011/402647

30. Zhang W., Ren X., Ouyang S., 2011 Development on ion substitution effect on the crystal structure and properties of tricalcium silikat Journal of Chineese. Ceramic Society vol 39 pp1666-1672

31. Zhang, H., He, PJ., Shao, LM. et al. 2008 Leaching behavior of heavy metals from municipal solid waste incineration bottom ash and its geochemical modeling, J Mater Cycles Waste Manag https://doi.org/10.1007/s10163-007-0191

32. Zmijowa D., Koliba M., Raclavski K 2018 Human Health Risk Assessment of Heavy Meatls Bound on Particulate Matter Inżynieria Mineralna Wyd. Polskiego Towarzystwa Przeróbki Kopalin, z. 1(41), s. 93-98, DOI: 10.29227/IM2018-01-15

Mechanizm immobilizacji kationów metali amfoterycznych $w$ mieszaninach iłowo-cementowych $W$ artykule przedstawiono możliwości zastosowania specjalnie przygotowanych spoiw w celu unieruchomienia migracji metali amfoterycznych. Spoiwa cementowo-iłowe to mieszanki zawierajace $w$ swoich składach spoiwo klinkierowe $i$ minerały ilaste, $w$ tym przypadku były to gliny Bełchatów i Koniecpol. Po procesie hydratacji mieszanki te tworza elastyczne i szczelne struktury, które sq wykorzystywane m.in. jako bariery unieruchamiające rozprzestrzenianie się zanieczyszczeń. Testy wykazały, że w przypadku metali amfoterycznych możliwa jest prawie 100\% akumulacja zanieczyszczeń $w$ strukturze zawiesin iłowo-cementowych. Podjęto również próbę wyjaśnienia mechanizmów zatrzymywania jonów w powstałych strukturach. W artykule przedstawiono trzy prawdopodobne mechanizmy wiązania jonów amfoterycznych, pierwszy to retencja $w$ przestrzeniach międzywarstwowych minerałów ilastych, drugi to uwięzienie w fazach typu CSH powstałych podczas hydratacji. Ostatnia możliwościa jest tworzenie nowych struktur krzemianowych.

Słowa kluczowe: jony amfoteryczne, zanieczyszczenie metalami, mieszanki gliny z cementem, hydratacja 
